\title{
Analisis Perlakuan Akuntansi Konstruksi Pengerjaan Dalam Penyajian Laporan Keuangan pada Dinas Pekerjaan Umum Kota Gorontalo
}

Zubaidah Rahman

\begin{abstract}
Prodi Akuntansi, Fakultas Ekonomi, Universitas Gorontalo
\end{abstract} Email: zubaidahrahman78 @gmail.com

\begin{abstract}
Abstrak
As for the purpose of this research was to determine the Accounting Treatment of Construction In the execution of the Financial Statements in the Public Works Department of the city of Gorontalo. How Accounting Treatment Construction In the execution of the Financial Statements in the Public Works Department of the city of Gorontalo

Based on the results presented earlier, it was found that the acquisition of fixed assets construction in progress on the means Public Dungingi Terminal and Pump House on the balance sheet at the Public Works Department of the city of Gorontalo not comply Treatment accounting, this can be seen in table 5.3 above, which shows the value of property and equipment construction in progress, construction in progress account in 2013 as records have been adjusted in the accounting treatment of $R p$ 6,725,491,000.00, it has been an accumulation value acquisition fixed assets construction in progress means Dungingi and Houses Public Terminal Pompatetapi not include the costs inherent in current procurement transactions means Dungingi Public Terminal and Pump house facilities
\end{abstract}

Keywords: Treatment of Accounting, Financial Statements

\section{PENDAHULUAN}

Indonesia adalah sebuah negara yang wilayahnya terbagi atas daerahdaerah provinsi. Daerah provinsi itu dibagi lagi atas daerah kabupaten dan daerah kota. Setiap daerah provinsi, kabupaten dan kota mempunyai pemerintahan daerah yang diatur dengan undang-undan. Pemerintah daerah merupakan penyelenggara urusan pemerintahan di daerah dan DPRD menurut asas otonomi daerah dan tugas pembantuan dengan prinsip otonomi yang seluas-luasnya dalam sistem dan prinsip negara kesatuan Republik Indonesia sebagaimana dimaksud dalam UUD 1945. 
Begitupun dengan keluarnya PeraturanPemerintah nomor 71 tahun 2010 tentang Standar Akuntansi Pemerintahan menetapkan pemerintah daerah dalam membuat laporan keuangan PeraturanPemerintah 71 tahun 2010 tersebut juga sangat penting bagi pemerintah daerah sebagai pedoman atau panduan dalam penyajian laporan keuangan serta menghindari terjadinya perbedaan persepsi dan pemahaman antara pemerintah daerah sebagai penyaji laporan dengan pengguna laporan serta pemeriksaan laporan keuangan (auditor).

Dengan adanya pembangunan di daerah yang dipacu melalui sarana dan prasarana maka Pemerintah Daerah harus lebih giat lagi untuk mencari sumber-sumber dana yang menanggulangi hal apa saja yang dibutuhkan oleh daerah untuk kemaslahatan umum.Dalam laporan keuangannya terdapat sumber-sumber aset, kewajiban, modal, pendapatan biaya yang dalam hal ini dapat memperlancar kegiatan-kegiatan program pemerintah.Dalam laporan kegiatan juga ada yang namanya Laporan Neraca yang berisi salah satunya aset pemerintah yaitu Konstruksi Dalam Pengerjaan. Berdasarkan latar belakang tersebut maka masalah pokok dalam penelitian ini adalah bagaimana perlakuan Akuntansi Konstruksi Dalam Pengerjaan dalam Penyajian Laporan Keuangan pada Dinas Pekerjaan Umum Kota Gorontalo

\section{LANDASAN TEORI DAN HIPOTESIS}

\subsection{Landasan Teori}

Akuntansi pemerintahan merupakan mekanisme akuntansi yang memperoleh transaksi keuangan yang berkaitan dengan pengelolaan keuangan Negara baik tingkat pusat maupun daerah. Mursyidi (2009: 1). Menurut Bastian (2001) akuntansi pemerintahan adalah sebagai mekanisme teknik dan analisis akuntansi yang diterapkan pada pengelolaan dana masyarakat dilembagalembaga tinggi negara, dan departemen-departemen dibawahnya, pemerintah daerah, BUMN, BUMD, LSM, dan yayasan sosial maupun pada proyek-proyek kerjasama sektor publik dan suwasta. Sedangkan akuntansi pemerinrahan menurut Halim (2007: 34) adalah data akuntansi digunakan untuk memberikan informasi mengenai transaksi ekonomi dan keuangan pemerintah kepada pihak eksekutif, legislatif, yudikatif, dan masyarakat.

Menurut Baridwan, (2000: 17) laporan keuangan merupakan ringkasan dari suatu peroses pencatatan dan transaksi-transaksi keuangan yang terjadi selama tahun buku yang bersangkutan yang dibuat oleh manajemen dengan tujuan untuk mempertanggungjawabkan yang diterabkan kepada pemimpin organisasi/entitas. Sedangkan menurut Mursyidi (2009: 59) laporan keuangan merupakan laporan keuangan yang disusun secara sistimatis mengenai posisi keuangan suatu entitas pada saat tertentu dan kinerja suatu entitas pada periode tertentu. Sedangkan dalam Peraturan Pemerintah Nomor 71 Tahun 2010 tentang SAP Nomor 08 adalah selain laporan keuangan tahunan, setiap entitas pelaporan juga diwajibkan menyusun laporan keuangan tentang pelaporan keuangan dan kinerja instansi pemerintah.

Aset adalah sumber daya ekonomi yang dikuasai dan/atau dimiliki oleh pemerintah sebagai akibat dari peristiwa masa lalu dan dari mana manfaat ekonomi dan/atau sosial di masa depan diharapkan dapat diperoleh, baik oleh pemerintah maupun masyarakat, serta dapat diukur dalam satuan uang, termasuk sumber daya nonkeuangan yang diperlukan untuk penyediaan jasa bagi masyarakat umum dan sumber-sumber daya yang dipelihara karena alasan 
sejarah dan budaya (dalam Peraturan Pemerintah Republik Indonesia Nomor 71 Tahun 2010: 43).

Pada Dinas Pekerjaan Umum Kota Gorontalo terdapat laporan keuangan yang memuat tentang Konstruksi Dalam Pengerjaan yang terdiri dari Nilai Perolehan dan Penyajian Laporan Keunagan. Nilai Perolehan tersebut melekat di dalamnya biaya-biaya sebagai berikut: (a) Biaya yang berhubungan langsung dengan kegiatan konstruksi, (b) biaya yang dapat diatribusikan pada kegiatan pada umumnya dan dapat dialokasikan kekonstruksi tersebut, dan (c) biaya lain yang secara khusus dibebankan sehubungan konstruksi yang bersangkutan. Sedangkan pada Penyajian Laporan Keunagan memuat tentang aset tetap berupa tanah dan bangunan, Jalan,Irigasi, jaringan serta ekuitas yang diinvestasikan dalam aset tetap. Sehingga pada nilai perolehannya bisa terlihat apakah sudah diterapkan atau belum diterapkan sesuai dengan Standar Akuntansi Pemerintahan.

\subsection{Hipotesis}

Sebagai dasar pemikiran dalam melakukan penelitian maka, pada penelitian ini diduga bahwa: "Perlakuan Akuntansi konstruksi dalam pengerjaan Dalam Penyajian laporan keuangan pada Dinas Pekerjaan Umum Kota Gorontalo belum diterapkan Sesuai Perlakuan Akuntansi”.

\section{METODE PENELITIAN}

\subsection{Jenis dan Sumber Data}

1. Jenis Data

a. Data kuantitatif, yaitu berupa angka-angka seperti dalam laporan keuangan untuk Perlakuan Akuntansi konstruksi dalam pengerjaan pada Dinas Pekerjaan Umum Kota Gorontalo.

b. Data kualitatif, yaitu berupa data-data yang memberikan penjelasan secara deskriptif tentang laporan hasil konstruksi dalam pengerjaan terhadap laporan neraca pada Dinas Pekerjaan Umum Kota Gorontalo

2. Sumber Data

a. Data primer, yaitu data yang diperoleh secara langsung dari para responden. Untuk memperoleh data tersebut dapat dilakukan dengan cara pengamatan langsung dan wawancara baik dengan pimpinan, staf dan semua pihak yang terkait dengan penulisan proposal ini.

b. Data sekunder, yaitu data yang diperoleh secara tertulis melalui perangkat system akuntansi, dan laporan perlakuan akuntansi yang terkait dengan penelitian ini.

\subsection{Metode Analisis}

1. Metode kualitatif yaitu metode deskriptif komparatif dengan menjelaskan dan membandingkan Perlakuan konstruksi dalam pengerjaan dalam laporan keuangan pada Dinas Pekerjaan Umum Kota Gorontalo dengan Perlakuan Akuntansi.

2. Metode kuantitatif yaitu menjelaskan tentang data-data dan bentuk angka-angka yang didapatkan dari objek penelitian yang berhubungan dengan nilai perolehan konstruksi dalam pengerjaan. 


\section{HASIL PENELITIAN DAN PEMBAHASAN}

\subsection{Hasil Penelitian}

Pada Dinas Pekerjaan Umum Kota Gorontalo secara garis besar struktural dan tupoksi (tugas pokok dan fungsi) masing-masing bidang, penyusunan laporan keuangan dilakukan oleh bidang keuangan.Dalam penelitian ini data yang digunakan adalah laporan neraca, susunannya terdiri dari tiga komponen utama yaitu Aset, Kewajiban, dan Ekuitas Dana. Sumber data yang digunakan tiga tahun anggaran yaitu tahun 2013 sampai tahun 2015, karena perolehan data dalam penelitian tersebut nilai perolehan aset tetap konstruksi dalam pengerjaan yang digunakan dalam pengolahan data hanya pada rekening Kontruksi Dalam Pengerjaan (KDP).

Pada Dinas Pekerjaan Umum Kota Gorontalo dalam pengambilan kebijakan pencatatan harga perolehan aset tetap kontruksi dalam pengerjaan pada pembangunan Terminal Dungingi dan Rumah Pompa belum sesuai dengan perlakuan akuntansi dikarenakan nilai perolehannya langsung diakumulasi dengan biaya-biaya yang melekat sampai Terminal Dungingi dan Rumah Pompa tersebut siap untuk di operasikan, pada tanggal 31 desember 2013 berjumlah Rp 6.725.491.000,- dan untuk KDP tahun 2012 sebesar RP 9.767.363.553,telah diakui sebagai aset,sehingga saldo kontruksi dalam pengerjaan per 31 Desember 2013 adalah murni pengerjaan yang kontraknya tahun 2013 yaitu pembangunan terminal dungingi sebesar Rp 6.534.700.000,-- dan pembangunan rumah pompa sebesar Rp 190.791.000,-

Pada Tahun 2014 Konstruksi dalam pengerjaan merupakan aset-aset yang sedang dalam proses pembangunan sampai dengan 31 Desember 2014 berjumlah Rp 22.076.108.061,00, dan untuk KDP Tahun 2013 sebesar 6.725.491.000,00 telah diakui sebagai aset, sehingga saldo Kontruksi dalam pengerjaan per 31 Desember 2014 adalah murni pekerjaan yang kontraknya tahun 2014 yaitu pembangunan sarana Publik terminal Dungingi sebesar Rp.20.478.492.405,- dan pembangunan pengerjaan rumah pompa sebesar Rp. 359.608.448,- dan Pembangunan Sarana Publik Terminal Dungingi sebesar Rp. 1.238.007.208,--

Pada Dinas Pekerjaan Umum Kota Gorontalo tahun 2013 dalam neraca perolehan Sarana Publik Terminal Dungingi sebesar Rp 6.725.491.000,00 nilai tersebut sudah termasuk biaya supervisi dan biaya dokumen perencanaan. Sehingga pencatatan harga perolehan aset tetap konstruksi dalam pengerjaan untuk Sarana Publik Terminal tersebut adalah nilai perolehan Sarana Publik tahun 2013 sebesar Rp 6.725.491.000,00, biaya supervisi dan biaya dokumentasi tidak mempunyai nominal sehingga saldo perolehan Sarana Publik terminal Dungingi dan Pompa dan reservior tahun 2013 sebesar Rp 6.725.491.000,00

Kemudian untuk tahun 2014 pada Dinas Pekerjaan Umum Kota Gorontalo nilai perolehan Sarana Publik Terminal Dungingi dan Pompa sebesar Rp 22.076.108.061,00, nilai tersebut sudah termasuk biaya supervisi dan biaya dokumen perencanaan. Sehingga pencatatan harga perolehan aset tetap konstruksi dalam pengerjaan untuk Sarana Publik Terminal tersebut adalah nilai perolehan Sarana Publik Terminal Dungingi tahun 2014 sebesar Rp 22.076.108.061,00,. Dan Pada Tahun 2015 Dinas Pekerjaan Umum Kota Gorontalo Nilai Perolehan Kontruksi dalam Pengerjaan yaitu sarana pelayanan publik terminal dungingi dan rumah pompa sebesar Rp. 34.770.267.272,-, nilai 
tersebut sudah termasuk biaya supervisi dan biaya dokumen perencanaan. Sehingga pencatatan harga perolehan aset tetap konstruksi dalam pengerjaan untuk Sarana Publik Terminal dungingi dan rumah pompa tersebut adalah nilai perolehan Sarana Publik Terminal Dungingi dan rumah pompa tahun 2015 sebesar Rp. 34.770.267.272.

\subsection{Pembahasan}

Kontruksi Dalam Pengerjaan merupakan aset-aset yang sedang dalam proses pembangunan, Berdasarkan pedoman yang diatur dalam Perlakuan Akuntansi, nilai perolehan aset tetap konstruksi dalam pengerjaan Sarana Publik Terminal Dungingi dan rumah Pompa belum sesuai dengan Perlakuan akuntansi dikarenakan perolehan aset tetap kontruksi dalam pengerjaan sarana Publik Terminal Dungingi dan Rumah Pompa telah mengakumulasi seluruh biaya-biaya yang seharusnya sesuai Perlakuan Akuntansi untuk konstruksi dalam pengerjaan sebelum dicatat dalam pembukuan/jurnal maka diharuskan mencatat biaya-biaya perolehannya. Untuk biaya perolehan yang melekat pada konstruksi dalam pengerjaan adalah :

(a) biaya yang berhubungan langsung dengan kegiatan konstruksi,

(b) biaya yang dapat diatribusikan pada kegiatan pada umumnya dan dapat dialokasikan kekonstruksi tersebut; dan

(c) biaya lain yang secara khusus dibebankan sehubungan konstruksi yang bersangkutan.

Seperti pada pembahasan perbandingan antara pencatatan perolehan aset tetap kontruksi dalam pengerjaan menurut pencatatan Dinas Pekerjaan Umum Kota Gorontalo dan menurut Perlakuan Akuntansi pada tabel berikut ini:

Tabel 1: Pencatatan perolehan aset tetap konstruksi dalam pengerjaan menurut pencatatan Dinas Pekerjaan Umum Kota Gorontalo tahun 2013 sampai tahun 2015.

Pencatatan perolehan asset tetap konstruksi dalam pengerjaan berdasarkan perlakuan akuntansi

\section{Tahun 2013}

Kontruksi Dalam Pengerjaan

Nilai Perolehan Terminal dan Rumah Pompa

Biaya Suvervisi

Biaya Dokumen Perencanaan

Perolehan Terminal dan Rumah Pompa

$\begin{array}{lr}\text { Rp } & 6,725,491,000 \\ R p & - \\ R p & - \\ R p & 6,725,491,000\end{array}$

Jurnal

Dr Biaya Bahan Bangunan

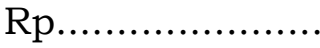

Dr Biaya Tenaga Kerja

Dr Biaya Lainnya

Rp...................

$\mathrm{Cr} \mathrm{R} / \mathrm{K}$ pusat

Rp.

Dr Kontruksi dalam pengerjaan

Cr Diinvestasikan dalam Aset Tetap

$\mathrm{Rp}$

6,725,491,000

Rp 6,725,491,000 


\section{Tahun 2014}

Kontruksi Dalam Pengerjaan

Nilai Perolehan Terminal dan Rumah Pompa

Rp 22,076,108,061

Biaya Suvervisi

Biaya Dokumen Perencanaan

$\mathrm{Rp}$

$\mathrm{Rp}$

Perolehan Terminal dan Rumah Pompa

Rp 22,076,108,061

Jurnal

Dr Biaya Bahan Bangunan

Rp.

Dr Biaya Tenaga Kerja

Rp.

Dr Biaya Lainnya

Cr R/K pusat

$\mathrm{Rp}$

$$
\text { (n.......... }
$$

Rp.

Dr Kontruksi dalam pengerjaan

Rp 22,076,108,061

Cr Diinvestasikan dalam Aset Tetap

Rp 2,076,108,061

\section{Tahun 2015}

Kontruksi Dalam Pengerjaan

Nilai Perolehan Terminal dan Rumah Pompa

Rp $34,770,267,272$

Biaya Suvervisi

Biaya Dokumen Perencanaan

$\mathrm{Rp}$

Perolehan Terminal dan Rumah Pompa

$\mathrm{Rp}$

Rp 34,770,267,272

Jurnal

Dr Biaya Bahan Bangunan

Dr Biaya Tenaga Kerja

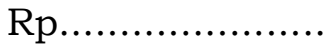

Dr Biaya Lainnya

$\mathrm{Cr} \mathrm{R} / \mathrm{K}$ pusat

Rp.

$\mathrm{Rp}$

Rp. ...........

Dr Kontruksi dalam pengerjaan

Rp 34,770,267,272

Cr Diinvestasikan dalam Aset Tetap

Rp $34,770,267,272$

Sumber : Data Olahan Tahun 2017

Tabel 2. Pencatatan perolehan aset tetap konstruksi dalam pengerjaan menurut Perlakuan Akuntansi tahun 2013 sampai tahun 2015

Pencatatan perolehan asset tetap konstruksi dalam pengerjaan Menurut Dinas Pekerjaan Umum Kota Gorontalo

\section{Tahun 2013}

Kontruksi Dalam Pengerjaan

Perolehan Terminal dan Rumah Pompa Tahun 2013 Rp 6,725,491,000

Jumlah Perolehan Terminal dan Rumah Pompa

Rp 6,725,491,000 
Jurnal

Dr Belanja Modal

Rp 6,725,491,000

Cr R/K Pusat

Rp 6,725,491,000

Dr Kontruksi dalam pengerjaan

Rp 6,725,491,000

Cr Diinvestasikan dalam Aset Tetap

Rp 6,725,491,000

\section{Tahun 2014}

Kontruksi Dalam Pengerjaan

Perolehan Terminal dan Rumah Pompa Tahun

2014

Jumlah Perolehan Terminal dan Rumah Pompa

Rp 22,076,108,061

Rp 22,076,108,061

Jurnal

Dr Belanja Modal

Cr R/K Pusat

Rp 22,076,108,061

Rp 22,076,108,061

Dr Kontruksi dalam pengerjaan

Cr Diinvestasikan dalam Aset Tetap

Rp $\quad 22,076,108,061$

Rp 22,076,108,061

\section{Tahun 2015}

Kontruksi Dalam Pengerjaan

Perolehan Terminal dan Rumah Pompa Tahun

2015

Rp 34,770,267,272

Jumlah Perolehan Terminal dan Rumah Pompa

Rp 34,770,267,272

Jurnal

Dr Belanja Modal

Cr R/K Pusat

Rp 34,770,267,272

Rp 34,770,267,272

Dr Kontruksi dalam pengerjaan

Cr Diinvestasikan dalam Aset Tetap

Rp 34,770,267,272

Rp 34,770,267,272

Sumber : Data Olahan Tahun 2017

Berdasarkan hasil penelitian yang dikemukakan sebelumnya, ditemukan bahwa perolehan aset tetap konstruksi dalam pengerjaan pada sarana Publik Terminal Dungingi dan Rumah Pompa pada neraca di Dinas Pekerjaan Umum Kota Gorontalo belum sesuai Perlakuan Akuntansi, hal ini dapat dilihat pada tabel 5.3 di atas, yang menunjukan nilai perolehan aset tetap konstruksi dalam pengerjaan, rekening Kontruksi dalam pengerjaan tahun 2013 sebagaimana pencatatan yang telah disesuaikan dalam Perlakuan Akuntansi sebesar Rp 6.725.491.000,00, nilai ini sudah merupakan akumulasi perolehan aset tetap konstruksi dalam pengerjaan sarana Publik Terminal Dungingi dan Rumah Pompatetapi belum termasuk dengan biaya-biaya yang melekat pada saat transaksi pengadaan sarana Publik Terminal Dungingi dan Rumah Pompa 
terjadi. Begitu pula dengan nilai perolehan pada pengadaan konstruksi dalam pengerjaan sarana Publik Terminal Dungingi dan Rumah Pompa tahun 2014, nilai perolehan aset tetap konstruksi dalam pengerjaan sarana Publik Terminal Dungingi dan Rumah Pompa yang sudah diakumulasi akan tetapi belum juga termasuk dengan biaya-biaya yang melekat pada saat transaksi Sarana Publik dan Rumah Pompa tersebut sebesar Rp 22.076.108.061,00.

Pada nilai perolehan aset tetap konstruksi dalam pengerjaan Sarana Publik Terminal Dungingi dan Rumah Pompa untuk tahun 2015 yang telah disesuaikan dengan Perlakuan Akuntansi berjumlah Rp 34.770.267.272,00,karena pada tahun tersebut juga belum termasuk pencatatan biaya-biaya yang berhubungan dengan pengadaan aset tetap konstruksi dalam pengerjaan Sarana Publik Terminal Dungingi dan Rumah Pompa tersebut seperti yang nampak pada jurnal sebesar Rp 34.770.267.272,00. Yang seharusnya dari seluruh nilai tersebut sudah termasuk biaya- biaya yang terjadi dalam perolehan aset tersebut diakumulasikan dengan nilai perolehan aset tetap konstruksi dalam pengerjaan Sarana Publik Termianal Dungingi dan Rumah Pompa tahun 2015 sebesar Rp 34.770.267.272,00 sehingga akan menghasilakn total nilai perolehan aset tetap konstruksi dalam pengerjaan Sarana Publik Terminal Dungingi dan Rumah Pompa lebih besar dibandingkan dengan pencatatan nilai perolehan aset tetap konstruksi dalam pengerjaan Sarana Publik Terminal Dungingi dan Rumah Pompa pada Dinas Pekerjaan Umum Kota Gorontalo pada tahun 2013 sampai dengan tahun 2015

Kebijakan yang terjadi pada Dinas Pekerjaan Umum Kota Gorontalo dalam penetapan nilai perolehan aset tetap konstruksi dalam pengerjaan Sarana Publik Terminal Dungingi dan Rumah Pompahanya dilihat dari keseluruhan nilai perolehan tanpa memisahkan biaya-biaya lain yang berhubungan dengan pengadaan aset tetap konstruksi dalam pengerjaan Sarana Publik Terminal Dungingi dan Rumah Pompatersebut. Biaya-biaya ini oleh Dinas Pekerjaan Umum Kota Gorontalo dicatat pada belanja modal dalam Laporan Realisasi Anggaran tanpa mencantumkan atau menambahkannya kedalam akun neraca untuk akun konstruksi dalam pengerjaan Sarana Publik Terminal Dungingi dan Rumah Pompa. Hal ini tidak sesuai dengan Perlakuan Akuntansi yaitu nilai aset tetap berwujud yang dianggarkan dalam belanja modal sebesar harga beli aset ditambah seluruh biaya yang terkait dengan pengadaan/pembangunan aset sampai aset tersebut siap digunakan. Oleh sebab itu nilai aset tetap konstruksi dalam pengerjaan Sarana Publik Terminal Dungingi dan Rumah Pompa pada Dinas Pekerjaan Umum Kota Gorontalo berjumlah lebih kecil dibandingkan dengan hasil perolehan aset tetap konstruksi dalam pengerjaan Sarana Publik Terminal Dungingi dan Rumah Pompa yang sudah disesuaikan dengan Perlakuan Akuntansi.

Dari hasil penelitian yang dilakukan menunjukan bahwa hipotesis peneliti terbukti yaitu perolehan aset tetap konstruksi dalam pengerjaan terhadap laporan Keuangan pada Dinas Pekerjaan Umum Kota Gorontalo belum sesuai dengan Perlakuan Akuntansi.

\section{SIMPULAN}

Berdasarkan hasil penelitian dan pembahasan pada Bab sebelumnya, maka dapat ditarik kesimpulan yaitu: 
(1). Nilai perolehan Aset Tetap konstruksi dalam pengerjaan Sarana Publik Terminal Dungingi dan Rumah Pompa pada DinasPekerjaanUmum (PU) Kota Gorontalo tidak melekatkan biaya-biaya yang terjadi pada saat pengadaan aset tetap konstruksi dalam pengerjaan tersebut dilaksanakan. Biaya-biaya yang dimaksud yaitu biaya Supervisi dan biaya Dokumen Perencanaan. Hal ini tidak sesuai dengan Perlakuan Akuntansi yaitu nilai Aset Tetap berwujud yang dianggarkan dalam belanja modal sebesar harga beli aset ditambah seluruh biaya yang terkait dengan pengadaan/pembanguan aset sampai aset tersebut siap digunakan.

(2). Penyajian Aset Tetap Konstruksi dalam pengerjaan Sarana Publik Terminal Dungingi dan Rumah Pompa pada DinasPekerjaanUmum (PU) Kota Gorontalo langsung mencatat nilai perolehannya pada Neraca untuk akun konstruksi dalam pengerjaan Sarana Publik Terminal Dungingi dan Rumah Pompa.

(3). Dari hasil penelitian yang dilakukan menunjukan bahwa hipotesis peneliti terbukti yaitu perolehan asset tetap konstruksi dalam pengerjaan terhadap laporan Keuangan pada Dinas Pekerjaan Umum (PU) Kota Gorontalo belum sesuai dengan Perlakuan Akuntansi.

\section{DAFTAR PUSTAKA}

Bastian, Indra.2001. AkuntansiSektorPublik di Indonesia.Yogyakarta: BPFE.

Bastian, Indra. 2006. Akuntansi Sektor Publik : Suatu Pengantar. Jakarta: PenerbitErlangga.

Baridwan. Z, 2003, Intermediate Accounting, BPEE, Yogyakarta.

Baswir, Revrison. 2000. Akuntansi Pemerintahan Indonesia. BPEF Yogyakarta.Yogyakarta.

Gade, Muhammad. 2000. Akuntansi Pemerintahan. Jakarta: Lembaga Penerbit Fakultas Ekonomi Universitas Indonesia.

Halim, Abdul, 2007, Bunga Rampai Manajemen Keuangan Daerah, UPP AMP YKPN, Yogyakarta.

Halim, Abdul, 2007. Akuntansi keuangan Daerah, Jakarta :Salemba Empat.

Haryono, Al, Jusup, 2005, Dasar - Dasar Akuntansi : Edisi Lima, Jakarta.

Haryono, Al. Jusup, 2003. Dasar-Dasar Akuntansi, Yogyakarta :Sekolah Tinggi Ilmu Ekonomi (STIE YKPN).

Harahap,Sofyan S, 2003, Teori Akuntansi,: Edisi Revisi, Penerbit Salemba Empat, Jakarta.

Mardiasmo, 2002.Akuntansi Sektor Publik, Yogyakarta :Andi Offset.

Mursyidi, 2009.Akuntansi Pemerintahan di Indonesia, Bandung: Refika Aditama.

Mahmudi, 2007.Analisis Laporan Keuangan Pemerintah Daerah,Yogyakarta : UPP STIN YKPM.

Nurdiawan,Deddi, 2006, Akuntansi Sektor Publik,: Penerbit Salemba Empa, Jakarta. 